\title{
Influences of Packaging on Consumers' Choice of Agricultural Products in Enugu, Nigeria
}

\author{
Ebube Chukwuebuka Wilfred", Tobenna Valentine Onyeakusiobi
}

Department of Marketing, University of Nigeria, Enugu Campus, Enugu State, Nigeria.

\section{A R T I C L E I N F O}

Research Article

Received 07 October 2016

Accepted 19 January 2017

Keywords

Packaging

Agricultural products

Consumer buying decision

Agro-product consumers

Perceived Quality

*Corresponding Author:

E-mail: wilfredchukwuebuka@ yahoo.com

\section{A B S T R A C T}

This study focused on packaging and its influence on consumers' choice of agricultural products in Enugu metropolis, Nigeria. In addition, it also aimed to ascertain the relationship between packaging of agricultural products and their perceived quality. The study population is made up of agro-product consumers in Enugu metropolis, Nigeria. A total of 165 questionnaires were administered to respondents. Data obtained through questionnaires were tabulated and analyzed using simple percentages while the chi-square was used to test the research hypotheses. The major findings of this study were that packaging has a direct relationship both to consumers' choice of agricultural products and their perception of the quality of such products. Accordingly, the researchers conclude and recommend that improved packaging design for agricultural products is essential in attracting consumers and positively influencing their choice of purchase.

DOI: https://doi.org/10.24925/turjaf.v5i5.484-487.1023

\section{Introduction}

Agriculture is a major sector of the Nigeria economy. From the nation's earliest days, agriculture has held a crucial place in the Nigerian economy and culture. The provision of food through agriculture is man's first priority for his continuous existence. Enugu metropolis is more of a consumer area of agricultural products produced in the rural areas of the state. The major agricultural products available in Enugu Metropolis include yam, potato, cabbage, maize, beans, rice, etc. The residents of the city are majorly self employed youths, business men and women, students and civil servants. There is a good number of markets, schools and administrative organizations in the city.

For many years, conjoint analysis has been used to estimate the importance of various products attributes for consumer's purchasing decisions (Green et al, 1990; Enneking et al, 2007). Packaging seems to be one of the most important factors in purchase decisions mainly at the point of sale (Prendergast et al, 1996). Packaging is also a key food product attribute perceived by consumers. There is no escaping the fact that packaging performs marketing functions. The critical importance of packaging is growing in such competitive market conditions as packaging becomes the primary vehicle for communication and branding (Rettie et al, 2000). The package standing on the shelf affects the consumer decision process and package design must ensure that response is favourable (Silayoi et al, 2004). The package is a critical factor in the decision making process because it communicates to consumers.
Pairing the correct product packaging with the right agricultural goods is crucial to successful distribution of such products. Each crop has different handling needs, which results in different types of packaging to ensure products arrive ready to sell and eat. No matter the crop, each type of produce packaging performs three basic functions:

- It offers ventilation to allow heat escape and accelerates the cooling of the package's content

- It reduces crop/produce water loss.

- It averts possible injury to products during transit and handling.

Marketing in agriculture involves a series of business activities involved in the sale and transfer of agricultural inputs from the farmers to purchasers of farm harvest or consumers. In other words, marketing in agriculture implies the various activities by which agricultural goods and services are supplied, advertised and sold to the farmers and consumers. It should be observed that marketing in agriculture connotes the activities of the following: farmers, transporters, middlemen, consumers. Marketing completes the basic principle of production. The main aim of every production is to satisfy people's needs and wants. Thus, production remains incomplete until goods and services get to the final consumers.It is against this background that this study seeks to assess the influence of packaging on consumers' choice of agricultural products. 
This study seeks to assess the influence of packaging in consumers' choice of agricultural products. Specifically, the study is aimed at identifying the following.

- To ascertain the influence of packaging of agricultural products on consumers' choice of agricultural products.

- To determine the relationship between perceived quality of agricultural products and their packaging.

- To determine the consumers' opinion about packaging indicators for agricultural product items.

Although the managerial focus towards packaging has increased, review of the marketing literature reveals few theoretical contributions in the area of packaging and relatively few efforts in relation to its impact on the marketing function such as consumer behaviour (Rundh, 2005). Specifically, there is also an evidence gap in relating packaging to agricultural product, more so in developing settings like Nigeria. It is in the light of the above statement that we seek to ascertain the influence of packaging on consumers' choice of agricultural products in Enugu Metropolis.

We hypothesize that Packaging of agricultural products has an impact on consumers' demand for agricultural products; that there is a relationship between the perceived quality of agricultural products and their packaging; and that Consumers' opinion of agricultural products is shaped by packaging indicators.

\section{Materials and Methods}

The study adopted a survey research design which involved the use of questionnaires to investigate the current opinion of the consumers regarding the influences of packaging on their buying behaviour in relation to agricultural products in Enugu metropolis. Enugu is the capital city of Enugu State, Nigeria. According to the National Population Commission 2006 census has a population of 722,664.All the consumers of agricultural products constituted the study population and the sample size was determined using Tuchman's formula. The sample size is 165 using $95 \%$ confidence level and 5\% level of significance. Convenience sampling technique was used in the study. Primary data was obtained through personal/oral interview and questionnaires. Specifically, textbooks, online journals, and materials downloaded from the internet constituted the secondary sources of information for this research. Data was presented using tables, frequencies and simple percentages. Chi-square was used to test all the research hypotheses formulated. The chi- square formula is given below:

$$
\chi_{0}^{2}=\sum \frac{\left(O_{i}-E_{i}\right)^{2}}{E_{i}}
$$

\footnotetext{
Where;

$\mathrm{X}^{2} \quad$ :Chi -square value

$\sum$ :Summation

$\mathrm{O}$ :Observed frequency

E :Expected frequency
}

The expected frequency is calculated thus:

$E=\frac{\sum F_{0}}{K}$

Where;

$\mathrm{F}_{0}$ :Observed frequency,

$\mathrm{K}$ :Number of rows

The degree of freedom is obtained using (K-1)

In hypothesis testing for acceptance or rejection, the following decision rule was employed;

Accept $\mathrm{H}_{\mathrm{o}}$ if $\mathrm{X}^{2}$ cal $>\mathrm{X}^{2}$ tab, do not reject if otherwise. $\mathrm{X}^{2}$ cal : Calculated chi-square value

$\mathrm{X}^{2}$ tab : Chi-square value from table of critical values

\section{Results and Discussion}

A total of 165 questionnaires were distributed and 25 were lost while 140 were returned. Therefore, the presentation and discussion of data was based on the 140 questionnaires returned.

Table 1 gives a summary of demographic characteristics of respondents. It shows that the majority of respondents were females $95(68 \%)$ while males were $45(32 \%)$, making it a total of 140 questionnaires that were distributed and returned. It equally shows that $80(57 \%)$ respondents are single; $60(43 \%)$ were married and none of the respondents is divorced. It also shows that $22(15.7 \%)$ of the respondents are less than 20 years; $65(46.4 \%)$ fall within the $21-29$ age bracket; $13(9.3 \%)$ fall within the 30-39 age bracket and 40(2.8\%) fall within the age bracket of 40 years and above. Ninety-five $(68 \%)$ respondents had secondary education while $45(32 \%)$ had tertiary education. Ninety $(64 \%)$ respondents were self employed; 40(29\%) were students, while 10(7\%) respondents were civil servants, and none identified as a farmer.

Table 2 shows that $100(71.4 \%)$ of the respondents are of the view that packaging have influenced their choice of agricultural products. 30(21\%) respondents are neutral while $10(7.14 \%)$ of the respondents were of the opinion that packaging does not influence consumers' choice of agricultural products.

Table 3 shows that $90(64.3 \%)$ of the respondents want agricultural products packaged. $42(30 \%)$ respondents are neutral while $8(5.7 \%)$ of the respondents want agricultural products unpackaged.

Table 4 shows that $90(64.3 \%)$ of the respondents believe that packaging affects consumers' perception of the quality of agricultural products;40(28.6\%) were neutral, while $10(7.13 \%)$ did not believe that packaging affects consumers' perception of the quality of agricultural products.

Table 5 shows that $107(76.4 \%)$ of the respondents agree that packaging indicators like, shape size and colour influence theirchoice of purchases for agricultural products; $18(12.9 \%)$ were neutral, while $15(10.7)$ of the respondents did not agree that packagingindicator like shape, size and colour influence their choice of purchase for agricultural products. 
Table 1 Demographic characteristics of respondents

\begin{tabular}{l|lcc}
\hline \multicolumn{1}{c}{ Variables } & \multicolumn{1}{|c}{ Options } & F & P \\
\hline \multirow{2}{*}{ Sex } & Female & 95 & 68 \\
& male & 45 & 32 \\
\hline \multirow{3}{*}{ Marital status } & Single & 80 & 57 \\
& Married & 60 & 43 \\
& Divorced & -- & -- \\
\hline \multirow{5}{*}{ Age group } & Less than 20 years & 22 & 15.7 \\
& 21-29 years & 65 & 46.4 \\
& 30-39 years & 13 & 9.3 \\
& Above 40 years & 40 & 28.5 \\
\hline \multirow{5}{*}{ Educational } & No formal education & -- & -- \\
& Primary education & -- & -- \\
& Secondary education & 95 & 68 \\
& Tertiary education & 45 & 32 \\
\hline \multirow{5}{*}{ Occupation } & Farmer & -- & -- \\
& Self Employed & 90 & 64 \\
& Students & 40 & 29 \\
& Civil servant & 10 & 7 \\
\hline F. Frequency, P: Percentage (\%), Source: Field Survey, & 2016 &
\end{tabular}

Table 2 Does packaging have any influence on consumers' choice of agricultural products?*

\begin{tabular}{l|cc}
\hline \multicolumn{1}{c|}{ Option } & Frequency & Percentage $(\%)$ \\
\hline Yes & 100 & 71.4 \\
Neutral & 30 & 21 \\
No & 10 & 7.14 \\
Total & 140 & 100 \\
\hline
\end{tabular}

*Source: Field Survey, 2016

Table 3 How would you like agricultural products presented to you?

\begin{tabular}{l|cc}
\multicolumn{1}{c}{ Option } & Frequency & Percentage $(\%)$ \\
\hline Packaged & 90 & 64.3 \\
Neutral & 42 & 30 \\
Unpackaged & 8 & 5.7 \\
Total & 140 & 100 \\
\hline
\end{tabular}

*Source: Field Survey, 2016

Table 4 Does packaging affect consumers' perception of the quality agricultural products?*

\begin{tabular}{l|cc}
\hline \multicolumn{1}{c}{ Option } & Frequency & Percentage (\%) \\
\hline Yes & 90 & 64.3 \\
Neutral & 40 & 28.6 \\
No & 10 & 7.13 \\
Total & 140 & 100 \\
\hline
\end{tabular}

*Source: Field Survey, 2016

Table 5 Do packaging indicators like shape, size and colour influence your choice of purchase for agricultural products?*

\begin{tabular}{l|cc}
\hline \multicolumn{1}{c|}{ Option } & Frequency & Percentage (\%) \\
\hline Yes & 107 & 76.4 \\
Neutral & 18 & 12.9 \\
No & 15 & 10.7 \\
Total & 140 & 100 \\
\hline
\end{tabular}

*Source: Field Survey, 2016

\section{Discussion}

This study examined the influence of packaging on consumers' choice of agricultural products in Enugu metropolis. Data obtained suggested that there were more females than males who visit supermarkets and other market places to buy agricultural products. This finding is similar to those of Ekeng et al., (2012) who asserted that it is not surprising as females are more culturally predisposed to shopping for domestic and family needs than men. Gham et al (2011) in Ekeng et al (2012) in their study reported that female shoppers in Pakistan are more inclined to packaging-induced impulse buying than the male shoppers.

The majority of the respondents in our study were adults between 21 and 60 years of age; although there were a few minors who participated in the survey; these may represent those who probably were sent to purchase agricultural products by their parents within the neighbourhood of the supermarkets and markets in the metropolis. The fact that majority of the respondents were literate implies that they were likely to be inclined to more modern packaging of agricultural products other than the traditional means. Their level of literacy will also influence their ability to read packaging information and analyse its effect on the durability and quality of the products so as to make informed decisions. Being an enterprising, education conscious and a civil service working population, income is likely to affect their purchase of agricultural products.

This implies that the respondents' choice of agricultural product to purchase will be influenced by price. The marital status was also noted to influence the frequency of purchase. This is probably because the married will purchase more because of their family size while independent youths will buy less though they are more in number.

The finding on the test of hypothesis on whether packaging has influence in consumers' choice of agricultural products, revealed that consumers will favour packaged agricultural products to unpackaged ones. This is consistent with the finding of Debevere (2004) in Belgium. In the study, consumer perception and choice of packaged fruits and vegetables was investigated through implementing a consumer survey in Belgium. The first part of the survey consisted of face- to face interviews $(n=294)$ at the point of sales with people buying packaging vegetable and fruits. The second part of the survey was self administered by consumers at home after consumption $(n=237)$ and it was discovered that the likelihood of buying packaged fruits and vegetables tends to be higher among better educated consumers and among consumers with young children. Also in a study by Luttenberger (2015) on food packaging, 30\% of consumers say they wish more bagged salads came in resalable packaging, while nearly $25 \%$ say they would like more fruits and vegetable in single-serve package. 
Furthermore, from our study result, it is cleart hat there is a positive relationship between the perceived quality of agricultural products and their packaging. Similarly, consumers' opinion of agricultural products is shown to be shaped by packaging indicators. This is consistent with the report of a study by Estiri et al (2010) who examined the relationship between packaging and food products consumer behaviours in Refah chain stores in Iran. In this study, the questionnaire filled by participants $(n=175)$ which were analysed qualitatively to examine the importance of different packaging elements on consumer behaviours in their stages of purchases. Results show that all packaging elements are highly important for food products buyers and these elements can highly influence their purchase decision. It also reveals that if an agricultural product is properly packaged, the demand will be high since there is high perceived quality in the mind of consumers of packaged agricultural products. Since $90(64.3 \%)$ of the respondents believe that packaging affects consumers' perception of the quality of agricultural products, it suggests that there will be an increase in the demand of agricultural product by at least $64 \%$ if packaged all things being equal. Packaging is a good positioning tool (Kotler, 2012)

\section{Conclusion and Recommendation}

Based on our study result and analysis, we conclude that packaging has a direct relationship on consumers' choice of agricultural products. Similarly, there is a positive relationship between perceived quality of agricultural product and their packaging; and that consumers' opinion of agricultural products is shaped by packaging attributes.

In the light of the above findings, we proffer the following recommendations to address the perceived problems facing the marketing of agricultural products in Enugu metropolis.

- Marketers of agricultural products should concentrate their effort on making the package designsufficiently attractive to attract the interest of the customers.

- The regulating agencies such as Standards Organization of Nigeria (SON) and National Agency for Food Drug, Administration and Control (NAFDAC) should provide a packaging standard for all categories of agricultural products marketed to Nigerian consumers.

- Nigerian consumers should insist on reasonably, good package standards for agricultural products. This will compel the producers and marketers of agricultural products to maintain a minimum acceptable standard in packaging their products.

- Packaging of agricultural products can also be encouraged by creating programmes or campaigns that showcase the importance or benefits of having agricultural products packaged.

- Government should make policies that will encourage farmers to package their products so that it doesn't get contaminated.
- An award should be giving to farmers that package their agricultural products. This will be an instrument of creating awareness for packaging of agricultural products and also encourage farmers to package their products.

- Government, its agencies, and researchers should collate and project the revenue and sales derived by these farmers or marketers of agricultural product so as encourage packaging of agricultural product.

\section{Acknowledgment}

We are hugely indebted toDr S.C. Moguluwa, Mr. Chidera Ugwuanyi, Dr. Chiedozie Ugwoke and Mr. Chunta Pius, they were of much assistance. May God reward you all abundantly.

\section{References}

Green PE, Srinivasan V. 1990. Conjoint Analysis in Consumer Research: Issues and Outlook, Journal of Consumer Research 5:103-123.

Prendergast PG, Pitt L. 1996. Packaging, Marketing, Logistics and the Environment; Is There Trade - Offs?. International Journal of Physical Distribution and Logistics Management; 26:60-72.

Rettie R, Brewer C. 2000. The Verbal and Visual Component of Package design. Journal of Product and Brand Management; 9:56-70.

Rundh B. 2005. The Multi-Facet Dimension of Packaging: Marketing Logistic or Marketing Tool? British Food Journal, 107: 670-684.

Silayo P, Speece M. 2004. Packaging and Purchase Decision: An Exploratory Study on the Impact of Involvement Level and Time Pressure. British Food Journal, 106: 607-628.

Achison CB. 2000. Industrial Marketing Enugu: Precision Printers and Publishers.

Fuller HB. 2014. Agricultural Packaging of Food New York: USA Prentice and Publishers.

Kotler P, Keller K. 2012, Marketing Management. England Pearson Horizon Editions

Kotler P, Gary A. 2000. Principles of Marketing England: Pearson Horizon Editions

Ubakamma EE, Ezeani IC, Eruchalu MC. 2000. Founder Agricultural Science. Onitsha: Mas Founders Publications Ltd.

Ugwuanyi WN, Ugwuanyi G. 1999. Agricultural Financial Management and Food Marketing Aguda Lagos: Johnkens and Willy Publishers Ltd.

Berkowitz EN, Kerin RA, Hartley SW. 2001. Marketing. $12^{\text {th }}$ ed. New York Mc-Graw Hill.

Edward B. 1979. Product policy and management. Macmillan Studies in Marketing management. London. UK. Macmillan Press Ltd.

Kano N, Seraku N, Takahashi F, Tujui S. 1984. Attractive Quality and Must. Be Quality. Hinshitsu 14(2): 147-56

Kerin EO, Ebue BC, Nnolim DA. 1997. Principles and Practice of Marketing. Enugu: John Jacob's classic publishers Ltd

Luttenberger D. 2015. Fresh Perspective on Produce Packaging, Packaging Digest. 2: 9-11

Ragaert P. 2004. Consumer Perceptionand Choice ofMinimally Processed Vegetable and Packaged Fruits. Sciences Direct; 15: 259-270 TerenceAS. 2000. Advertising Promotions. Supplemental Aspect of Integrated Marketing Communications. Port Harcourt College Publishers. $5^{\text {th }}$ ed.

Terence AS. 2000. Advertising Promotions. Supplemental Aspect of Integrated Marketing Communications. Port Harcourt College Publishers. 5thed 